\title{
Modelling Supported Design of Light Management Structures in Ultra-Thin CIGS Photovoltaic Devices
}

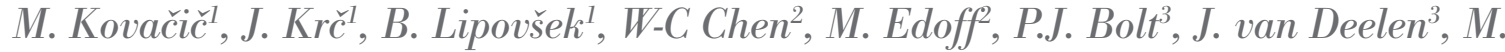 \\ Zhukova ${ }^{4}$, \\ J. Lontchi ${ }^{4}$, D. Flandre ${ }^{4}$, P. Salomé $e^{5}$ and M. Topič ${ }^{1}$
}

${ }^{1}$ University of Ljubljana, Faculty of Electrical Engineering, Ljubljana, Slovenia ${ }^{2}$ Uppsala University, dep. Eng. Sciences, Angstrom lab, Uppsala, Sweden ${ }^{3}$ TNO, Solar Technology and Applications, AE Eindhoven, The Netherlands ${ }^{4}$ Université catholique de Louvain, ICTEAM institute, Louvain-la-Neuve, Belgium ${ }^{5}$ International Iberian Nanotechnology Laboratory, Braga, Portugal

\begin{abstract}
Chalcopyrite solar cells exhibit one of the highest conversion efficiencies among thin-film solar cell technologies (> 23.3\%), however a considerably thick absorber $\geq 1.8 \mu \mathrm{m}$ is required for an efficient absorption of the long-wavelength light and collection of charge carriers. In order to minimize the material consumption and to accelerate the fabrication process, further thinning down of the absorber layer is important. Using a thin absorber layer results in a highly reduced photocurrent density and to compensate for it an effective light management needs to be introduced. Experimentally supported, advanced optical simulations in a PV module configuration, i.e. solar cell structure including the encapsulation and front glass are employed to design solutions to increase the short current density of devices with ultra-thin $(500 \mathrm{~nm}$ ) absorbers. In particular (i) highly reflective metal back reflector (BR), (ii) internal nano-textures and (iii) external textures by applying a light management (LM) foil are investigated by simulations. Experimental verification of simulation results is presented for the external texture case. In the scope of this contribution we show that any individual aforementioned approach is not sufficient to compensate for the short circuit current drop of the thin CIGS, but only a combination of highly reflective back contact and introduction of textures (internal or external) is able to compensate and also to exceed (by more than $5 \%$ for internal texture) photocurrent density of a thick (1800 nm) CIGS absorber.
\end{abstract}

Keywords: ultra-thin CIGS solar cells, light management, textured interfaces, optical modelling

\section{Načrtovanje struktur za upravljanje svetlobe $v$ izredno tankih CIGS fotonapetostnih strukturah z uporabo modeliranja}

\begin{abstract}
Izvleček: Sončne celice na osnovi Cu(In, Ga)Se2 dosegajo relativno visoke učinkovitosti pretvorbe (> 23,3\%) v primerjavi z drugimi tankoplastnimi tehnologijami sončnih celic. Za učinkovito absorpcijo dolgovalovne svetlobe potrebujemo $\geq 1800 \mathrm{~nm}$ debelo absorpcijsko plast Cu(In, Ga)Se2. Z namenom zmanjšanja porabe materiala (predvsem In) in pohitritve nanosa absorpcijske plasti poskušamo najti rešitve, ki bi omogočile uporabo tanjših plasti, hkrati pa zagotovile primerljive učinkovitosti pretvorbe, ki jih dosežemo s standardnimi debelinami. Stanjšanje absorpcijske plasti samo po sebi vodi k zmanjšanju fototoka (zaradi nepopolne absorpcije dolgovalovne svetlobe), kar narekuje uporabo posebnih tehnik upravljanja svetlobe znotraj sončne celice. V tem prispevku z uporabo optičnih simulacij raziščemo potencial izbranih tehnik izboljšanja ujetja svetlobe in s tem povečanja absorpcije v strukturi s 500 nm debelo absorpcijsko plastjo. S simulacijami raziščemo učinke (i) visokoodbojnih zadnjih kovinskih odbojnikov, (ii) nanotekstur, prenešenih v celico preko hrapave površine substrata in (iii) zunanjih mikrotekstur, izdelanih na folijah na sprednjem steklu. Slednje ovrednotimo tudi na osnovi eksperimentalnih rezultatov. Rezultati simulacij pokažejo, da za ohranjanje fototoka prvotne celice z debelo plastjo, v tanki celici potrebujemo visokoodbojni zadnji odbojnik (na primer srebro), v kombinaciji z notranjimi ali zunanjimi teksturami. Z delno optimizacijo struktur lahko na celici s $500 \mathrm{~nm}$ debelo absorpcijsko plastjo celo presežemo fototok celice s $1800 \mathrm{~nm}$ debelo plastjo.

Corresponding Author's e-mail:milan.kovacic@fe.uni-lj.si
\end{abstract}

Ključne besede: zelo tanke sončne celice CIGS, upravljanje svetlobe, hrapavi spoji, optično modeliranje 


\section{Introduction}

Among thin film solar cell technologies, one of the highest efficiencies are achieved by a direct bandgap semiconductor $\mathrm{Cu}(\mathrm{In}, \mathrm{Ga}) \mathrm{Se}_{2}(\mathrm{CIGS})$, with a current record of $23.35 \%$ on the cell level [1]. CIGS exhibits high absorption but a fairly thick absorber $(\sim 2-3 \mu \mathrm{m})$ needs to be used. As CIGS alloys consist of scarce materials, especially indium and gallium $[2,3]$ the minimization of material consumption by reducing the thickness of the CIGS absorber layer is of high interest $[4,5]$. Besides reduced material usage faster throughput in CIGS deposition process is achieved. By thinning down the CIGS absorber from $1800 \mathrm{~nm}$ to $500 \mathrm{~nm}$ we expect the reduction of corresponding bill of material (BOM) costs from $31 \mathrm{USD} /$ module to $27 \mathrm{USD} /$ module, including an increased cost of the back contact (reflector) to maintain the conversion efficiency at the same level.

The usage of ultra-thin CIGS absorber layers $\left(d_{\text {CIGS }} \leq 500\right.$ $\mathrm{nm}$ ) comes with two main drawbacks. First is reduced short-circuit current density (Jsc) due to insufficiently absorbed long-wavelength light in the thin absorber. Second, open circuit voltage (Voc) and fill factor (FF) are affected. This is because in thinner CIGS cells, absorption of light takes place closer to the back contact, increasing the concentration of majority (holes) and minority (electron) carriers, thus, more carriers are exposed to surface defects at the back contact interface. Threreby recombination of charge carriers is increased compared to cells with thick CIGS absorber layers. Additionally, if texturing is introduced to improve light trapping, the surface area becomes larger and may lead to additional recombination.

Thin passivation layers (e.g. $\mathrm{Al}_{2} \mathrm{O}_{3}$ ) have already been successfully used at the rear Mo/CIGS interface to reduce surface recombination [6-9]. On the other hand, to compensate for reduced photocurrent density due to reduced thickness, an additional treatment to increase light absorption in the thin absorber needs to be introduced. Proposed solutions are well summarized in a review paper by Schmidt [10], and include improving front transparent contacts, using alternative window layers, implementing anti-reflecting structures, inclusion of efficient back reflectors, introduction of textures and nano-particles to induce light scattering and other.

In this contribution we focus on improving light absorption in ultra-thin $\left(d_{\text {CIGS }} \leq 500 \mathrm{~nm}\right)$ CIGS absorbers by means of numerical simulations. The optimization is carried out on simplified photovoltaic (PV) module structures where front glass and encapsulation foil (Ethyl Vinyl Acetate - EVA) are considered to form one incoherent thick layer on top of the solar cell in simula- tions. This simplification is based on low difference in refractive indices of EVA and glass.

Using simulations, we deduce that the main optical losses in the thin film structure are reduced absorption at longer wavelengths in CIGS layer and high absorption losses in the Mo back reflector. To improve the photocurrent density, we introduce (i) a highly reflective metal material - $\mathrm{Ag}$ as an alternative back reflector (BR), (ii) texturization on back (nano-textured BR) and front (micro-textures on top of encapsulation) side of the cell and (iii) a combination of both approaches. An additional thin $\mathrm{Al}_{2} \mathrm{O}_{3}$ layer on top of the metal $\mathrm{BR}$ is used both as a passivation of the CIGS rear surface and as a diffusion barrier for metals, preventing their diffusion into the CIGS layer during the evaporation process.

We show that only an alternative BR or only texturization is not sufficient to compensate for reduced photocurrent density when thinning down the absorber thickness from standard $1800 \mathrm{~nm}$ to $500 \mathrm{~nm}$. Combination of both, thus texturization (at front or back) and alternative BR needs to be employed in thin absorber devices to reach and even surpass standard thick devices.

\section{Modelling and Simulations}

Structures with flat and nanotextured interfaces were simulated with three-dimensional simulator Comsol Multiphysics [11], which uses Finite Element Method (FEM) to solve the Maxwell equations. FEM enables modelling of the exact morphology of (periodic) nanotextured interfaces in three dimensional structures. Such rigorous analysis in combination with realistic complex refractive indices of materials [12] enables to include various effects in simulation, such as light scattering and anti-reflection due to nanotexturing, as well as plasmonic absorption that can occur at textured metallic surfaces. However, it only considers coherent propagation of light in thin layers. Therefore, for the thick protection glass and encapsulation foil, we use a previously developed method that extends the applicability of the FEM method also to treatment of thick low absorbing incoherent layers [13]. By adding more incoherent layers, however, the computation time increases, since FEM simulation has to be carried out more times.

A combined wave optics / ray tracing simulator CROWM [14] was used when larger textures with features from several $\mu \mathrm{m}$ to $\mathrm{mm}$, like the texture of the light management (LM) foil, are modeled. Using CROWM an entire PV module with included LM foil is modelled. Here, adding more incoherent layers is not a problem, however, due to the reason of comparison we kept the 
encapsulation stack as one layer as in the case of FEM simulations. In CROWM thin coherent layers of the solar cell are simulated using a transfer matrix method and are combined with full three-dimensional ray tracing in micro-textured incoherent layers.

Presented models are used to simulate wavelengthdependent reflectance and absorptance of individual layers. As lateral dimensions of the structures are expected to be much larger than vertical ones, edge effects in simulations are neglected (but are possible to be included). All models were calibrated according to the literature [12] and measurement results - see Section 5.

Main external solar cell parameters, like $E Q E$ and $J_{\text {sc' }^{\prime}}$ which are directly linked to optical behavior of solar cells, are determined by considering an ideal extraction of charge carriers from the CIGS absorber by assuming low level of bulk and surface recombination. Bulk recombination can be minimized by high quality CIGS material obtained by a co-evaporation process and surface recombination can be minimized by using an efficient surface passivation layer [6], like $\mathrm{Al}_{2} \mathrm{O}_{3}$. In the simulations, contributions of generated carriers from the CdS layer were neglected [15]. Thus, external quantum efficiency $(E Q E)$ is matched with wavelength dependent absorptance in the CIGS layer $\left(E Q E_{\text {opt }}\right)$. The short circuit density $\left(J_{s c}\right)$ is then calculated by integrating the product of the AM1.5g solar spectrum and the $E Q E_{\text {opt }}$ across all wavelengths of the solar spectrum.

\section{Device structure and textures}

A schematic cross-section of a CIGS solar cell with included front encapsulation and rear $\mathrm{Al}_{2} \mathrm{O}_{3}$ passivation layer is presented in Figure 1(a). Solar cell layers are deposited on a soda lime glass (SLG) substrate in the following order: an opaque Mo layer ( $400 \mathrm{~nm}$ ) serving as an electrical contact and a BR in the basic case. This is followed by an optional alternative $\mathrm{BR}$ and an $\mathrm{Al}_{2} \mathrm{O}_{3}$ passivation layer. Next, we have an absorbing CIGS layer followed by a CdS, ZnO and ZnO:Al. In the case of a Mo back contact, a thin ( $5 \mathrm{~nm}$ ) interfacial layer $\left(\mathrm{MoSe}_{2}\right)$ is formed during deposition of the CIGS [16], resulting in a decreased reflectance of an ideal CIGS/Mo interface by about 20-25\% [17]. Passivation $\mathrm{Al}_{2} \mathrm{O}_{3}$ layers also serve as protective layers to prevent diffusion of metals into CIGS during deposition. $\mathrm{As}_{2} \mathrm{Al}_{2} \mathrm{O}_{3}$ is a non-conducting material, electrical contact is provided by an array of holes - point contacts in the $\mathrm{Al}_{2} \mathrm{O}_{3}$ layer [6-9]. Dimensions of these holes are sufficiently small (diameter $100 \sim 200 \mathrm{~nm}$, with pitch of $1 \sim 2 \mu \mathrm{m}$ ), as compared to the wavelength of light and thus do not contribute any significant amount to the optical effects and can thus be neglected in our optical simulations. Small dimensions and low density of the holes is also important from the point of view of the BR (Ag) material diffusion through the holes into CIGS, which can deteriorate the cell electrical performance. To minimize this effect thin Ag layer under these openings can be etched away and Mo takes the role of the local contact point. An alternative to prevent Ag diffusion into CIGS is to use TCO layer as Ag cover [18]. TCO layers (e.g. indium tin oxide) can bring some additional parasitic losses, but works as a diffusion barrier. Anyway, in this work we check optical benefits of the concept with a patterned thin $\mathrm{Al}_{2} \mathrm{O}_{3}$ layer, assuming to provide high quality passivation and sufficient diffusion barrier for Ag.

Finally, the cell is finished with an encapsulation consisting of two optically thick layers - EVA and glass (both are in $\mathrm{mm}$ range). In simulations both layers, EVA and glass, are considered as a single layer, due to good matching in refractive indices of both materials. Presented structure serves as a base model for all further simulations, with thicknesses and basic structure kept constant for all simulations.

To improve optical performance of thin CIGS, in addition to alternative highly reflective $\mathrm{BR}$, we also introduce internal nano-textures and external microtextures (LM foil) in simulations. The position of the internal and external textures can be seen in Figure 1(a), while its shape and size can be seen in Figure 1(b) and (c), respectively.

In our previous work, a detailed optical analysis of different internal textures introduced at the rear side of the device was performed [12], thus here we only use an optimal texture in our analysis. We selected a periodic two-dimensional, sine-like nano-texture with $P=$ $800 \mathrm{~nm}$ and $h=300 \mathrm{~nm}$ (see inset of Figure 1(b)), that can be fabricated on silicon or glass master by e-beam or etching techniques [19]. Applicability, with UV nanoimprint lithography makes these textures viable for low-cost, industrial scale production. Sine-like shape of nano-texture is also beneficial as it exhibits a smooth surface without any abrupt changes, reducing the risk of creating defects in the structure. Moreover, sine-like textures showed good results also in other solar cell technologies, like thin c-Si [20] and perovskite-silicon tandems [21]. Deposition of thin film layers on top of the nano-textures transfers the textured shape of the BR to the front side of the thin-film stack. As the layer growth is non-conformal, with a combination of isotropic and conformal growth, in our specific case the ratio of 0.3 (for details on layer growth see [22, 23], this results in changes in interface morphology as can be observed in Figure 1(b). 
a)

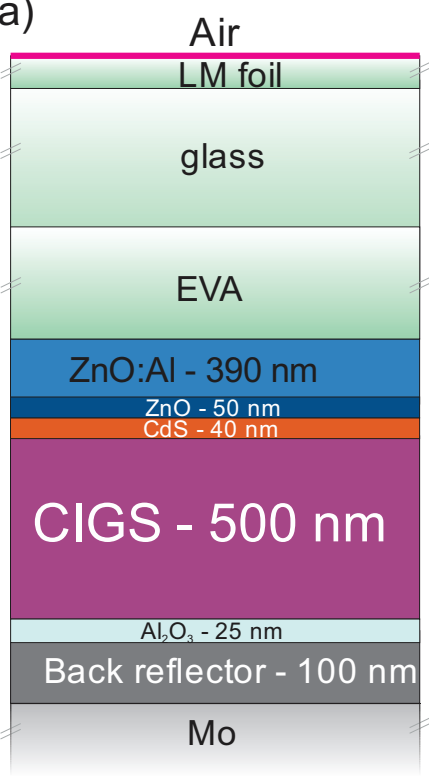

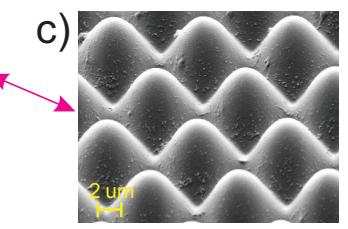

b)

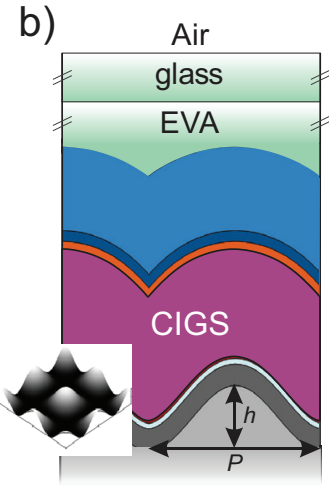

Figure 1: (a) A schematic cross-section of the CIGS PV module structure, (b) Cross-section of the structure with internal texture and non-conformal layer growth considered, (c) A Scanning electron microscopy image of hexagonal array of dome shaped micro-texture applied to the LM foil on top of front glass.

Alternative to texturing the $\mathrm{BR}$, we can also apply texture on the front interface. We introduce a LM foil (lacquer or PDMS material) on top of the cell (at the air / encapsulation interface) on which the texture is realized (e.g. via embossing); by this we keep all other interfaces flat. In this work we focused on a standard commercially available hexagonal array of $\mathrm{O}$ shaped domes, with pe$\operatorname{riod} P=7.38 \mu \mathrm{m}$ and height $h=5.5 \mu \mathrm{m}$ see Figure 1 (c). These structures already show potential for increasing $J_{\text {sc }}$ in other solar cell technologies [24-27]. The LM foil is implemented on top of the encapsulation and is in simulations considered as a part of the encapsulation. This is reasonable, as refractive indices of the foil and the glass (also EVA) are sufficiently close together ( $n=$ $1.35-1.5)$, thus can be treated as a single layer. This was confirmed by additional simulations where all three incoherent layers were treated separately as a three layer stack. In simulations of the structure with the LM foil with micro-sized texture ray optics in combination with thin-film optics (CROWM simulator) was used.

\section{Results and discussion}

To identify main optical losses when thinning down the CIGS absorber layer, we simulate a module with a thin $\left(d_{\mathrm{CIGS}}=500 \mathrm{~nm}\right)$ and a standard thick $\left(d_{\mathrm{CIGS}}=1800\right.$ nm) CIGS absorber. Comparison of EQE ${ }_{\text {opt }}$ and parasitic absorptions in BR (see Figure 2) reveals two main

loss mechanisms occurring when thinning down the absorber layer. Due to thinner absorber layer, highly reduced absorption of long-wavelength light, starting already at $550 \mathrm{~nm}$ can be observed. Secondly, as more light reaches the BR (less light is absorbed in the absorber) we can notice highly increased absorption losses in the $\mathrm{Mo}+\mathrm{MoSe}_{2} \mathrm{BR}$ - see Figure 2. On the other hand, reflection and parasitic absorption losses in other layers remain almost unaffected between thin and thick absorbers. Optical losses altogether result in a highly reduced short circuit current of $28.31 \mathrm{~mA} / \mathrm{cm}^{2}$ of the thin module, compared to the $33.04 \mathrm{~mA} / \mathrm{cm}^{2}$ of the standard thick one, which is more than a $14 \%$ decrease.

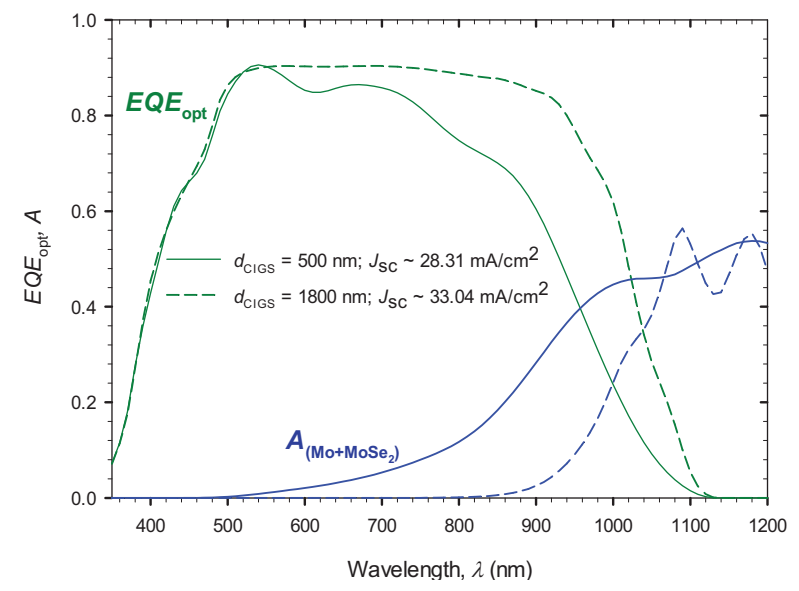

Figure 2: $E Q E_{\mathrm{opt}}\left(A_{\mathrm{CIGS}}\right)$ and $\mathrm{BR}$ absorption in standard thin $\left(d_{\text {CIGS }}=500 \mathrm{~nm}\right)$ and thick $\left(d_{\text {CIGS }}=1800 \mathrm{~nm}\right)$ CIGS module.

Both main loss mechanisms of thin devices are addressed in this contribution. First, we propose to replace the highly absorbing, poorly reflecting $B R$ $\left(\mathrm{MoSe}_{2} / \mathrm{Mo}\right)$ with alternative highly reflective metal BR, reducing absorption losses. To enhance absorption of long wavelength light, we propose texturization either on front or back side of the device, by which we can induce light scattering, light trapping and also antireflection properties, which if properly designed elongate the light path through the absorber, enabling also the long wavelength light to be absorbed.

\subsection{Alternative BR}

As a reference point, we simulate a thin device with a standard Mo BR, which results in a low $J_{\text {sc }}=28.17 \mathrm{~mA} /$ $\mathrm{cm}^{2}$. When introducing an alternative metal-based $\mathrm{BR}$, an additional $\mathrm{Al}_{2} \mathrm{O}_{3}$ passivation layer is also added to prevent diffusion of metals into the absorber during high temperature CIGS deposition. Adding $\mathrm{Al}_{2} \mathrm{O}_{3}$ to the existing Mo already increases the $J_{\mathrm{sc}}$ to $28.86 \mathrm{~mA} /$ $\mathrm{cm}^{2}$, although not due to the increased reflection, but 
due to reduced parasitic absorption losses enabled by the absence of the interfacial $\mathrm{MoSe}_{2}$ layer. Using a highly reflective metal $B R$ results in higher $J_{\text {sc }}$ due to highly reduced absorption losses in the BR. Using an Ag BR resulted in $J_{\mathrm{sc}}=30.85 \mathrm{~mA} / \mathrm{cm}^{2}$ - see Figure 3. Data show that for a more reflecting $B R$, a higher gain in $J_{s c}$ is achievable. However, although a high $J_{s c}$ of $30.85 \mathrm{~mA} /$ $\mathrm{cm}^{2}$ was achieved, it is still lower than the one of the standard thick device. An additional optical treatment is necessary to reach the $J_{\text {sc }}$ of the thick device.

\subsection{Internal textures}

To additionally improve the $J_{s c}$ of the thin CIGS solar cells, we introduce texturization of the BR in simulations. Nanotextures in general induce scattering of light which may improve light trapping inside the CIGS absorber and due to transfer of texture from the textured substrate to the front side (see Figure 1(b)) may also act as an antireflection structure at the front interfaces. The textures can be introduced in the structure of CIGS device e.g. by applying textured substrate. Using 3D FEM simulations, we simulated a PV module device with presented periodic internal sine-like nanotexture (see Figure 1(b)).

Simulations have been performed for the structures with different $\mathrm{BR}$, namely MoSe $/ \mathrm{Mo}$ - as a base example, $\mathrm{Al}_{2} \mathrm{O}_{3} / \mathrm{Mo}$ and $\mathrm{Al}_{2} \mathrm{O}_{3} / \mathrm{Ag}$. The general observation is that texturizing helps to improve $J_{\text {sc }}$ towards the device without the texturization in all cases - see Figure 3. Additionally, we can notice that high $J_{s c}$ is achieved with a highly reflecting $\mathrm{Ag} B R$. The main gain this time is due to the enhanced CIGS absorption in the long wavelength regime. By introducing optimized texturing, the optical path through the absorber is elongated, due to scattering and light trapping, thus additional light with longer wavelengths can be absorbed, contribut-

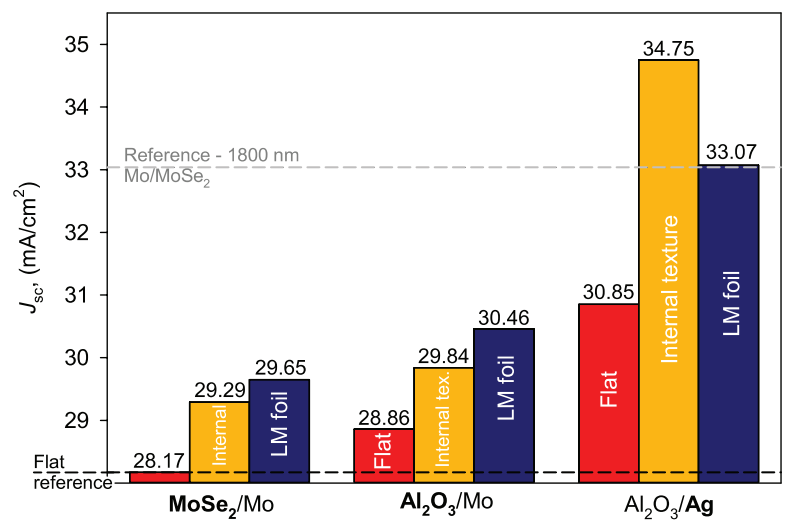

Figure 3: Comparison of simulated $J$ for CIGS PV modules without textures - flat (red bars), with internal textures (yellow bars) and with external textures (blue bars) on different BR. ing to higher $J_{\text {sc }}$. Here the highest $J_{\text {sc }}$ of $34.75 \mathrm{~mA} / \mathrm{cm}^{2}$ is achieved with the Ag BR surpassed the $J_{\text {sc }}$ of thick CIGS absorber by $5.1 \%$.

On the other hand, using a Mo BR, the increase in $J_{s c}$ is much lower, and with a $J_{\text {sc }}$ of $31.16 \mathrm{~mA} / \mathrm{cm}^{2}$ we are more than $5.7 \%$ below $J_{\text {sc }}$ of the thick absorber. Additionally, results show that contribution of a textured Mo BR is lower compared to only replacing Mo with a highly reflective $\mathrm{Ag} \mathrm{BR}$ in a flat device.

\subsection{External textures}

Alternative to the internal textures introduced previously are external textures that offer the advantage of an easy integration while at the same time not directly influencing the electrical properties of the device, as they are not in contact with any of the active layers. We introduce LM foil on top of the PV-module - at the air / encapsulation interface, while keeping all other interfaces flat - see Figure $1(\mathrm{a}, \mathrm{c})$.

Feature sizes of the presented textures are in the range of several micrometers, which requires geometrical optics to be used in this case. Textures importantly affect redirection of reflected and transmitted light, resulting in possible multiple entering events as well as redirection of rays propagating inside the structure. Similar as with internal textures, external textures were also tested with different BR. In general, results indicate an increase in Jsc for all BR. With better reflecting Ag $B R$, higher gains in Jsc are achievable, similarly as with internal textures. Slightly higher improvements compared to internal textures are noticeable for poorly reflecting Mo BR.

Simulation results reveal that a $\mathrm{LM}$ foil with an $\mathrm{Ag} B R$ increases the $J_{\text {sc }}$ up to $33.07 \mathrm{~mA} / \mathrm{cm}^{2}$. For Mo and $\mathrm{Mo} /$ $\mathrm{Al}_{2} \mathrm{O}_{3} \mathrm{BR}, J_{\text {sc }}$ is also increased compared to the structure without the LM foil to $29.65 \mathrm{~mA} / \mathrm{cm}^{2}$ and $30.46 \mathrm{~mA}$ / $\mathrm{cm}^{2}$, respectively. Although values are much higher than with textured Mo BR, these are still well below standard $1800 \mathrm{~nm}$ CIGS cell. Comparing $E Q E_{\text {opt }}$ and $R$ (not shown here) of a standard cell with a cell with LM foil reveals that the LM foil improves $R$ over the entire wavelength range, minimizing reflection losses and as a result higher $A_{\text {CIGS }}$ can be observed over the entire spectrum, not only at longer wavelengths as with textured BR. Again, we can notice that external textures without improved BR, similarly to internal textures, do not enhance the $J_{\text {sc }}$ enough to match or exceed standard the $1800 \mathrm{~nm}$ cell (see Figure 3). On the other hand, the usage of external textures in combination with a good BR (Ag), compensates for the reduced CIGS absorber layer thickness (1800 -> $500 \mathrm{~nm}$ ) and similar to internal textures, although only slightly, exceeds the 
standard thick CIGS cell. By optimization of the LM foil texture (e.g. aspect ratio) or by using different textures, even higher $J_{s c}$ could be achieved [12].

\subsection{Experimental results on external texture}

To check the improvements related to the external LM foil and validate the predictions of optical simulations ultra-thin CIGS solar cells $\left(d_{\mathrm{CIGS}}=330 \mathrm{~nm}\right.$ in this case) were fabricated on a flat substrate. Details on solar cell fabrication can be found in [28]. Mo was used as a rear contact material. An EQE of individual cells is measured in three different configurations: i) a bare cell, ii) a cell with added glass layer and iii) a cell with added glass layer and a LM foil. Both, glass and LM foils are attached to the solar cell using BK-7 matching liquid (Cargille laboratories, $\left.\mathrm{n}(589.3 \mathrm{~nm})=1.5167 @ 25^{\circ} \mathrm{C}\right)$. This enables us to measure the same cell in three different configurations, eliminating possible deviations between different cells and, thus, contributing measured differences entirely on changed optical properties due to added glass and external texture. In simulations, ideal extraction of charge carriers is assumed as in previous cases, while in the experimental case, due to the use of an ultra-thin absorber, charge carrier recombination losses at the back contact may start to affect carrier collection and extraction. To compensate for this non-ideal extraction all simulated EQEs are corrected by the same constant factor of 0.85 . This enables us to compare simulation and measurement results in absolute scale.

In Figure 4(b), a selected case of EQE measurements of a cell in (i), (ii) and (iii) configurations are presented, while in Figure 4(a) simulation results are given. First, we can notice the same trends in measured and simulated cases for all tree configurations. Next, adding a non-absorbing glass already increases the EQE resulting in an average of $3 \%$ (simulated $2.8 \%$ ) $J_{s c}$ improvement. Moreover, adding LM foil on top of the glass additionally increases the $E Q E$ over the entire spectrum, improving $J_{\text {sc }}$ in average by additionally $5 \%$ (simulated $6.2 \%)$.

\section{Conclusion}

Using optical modelling we first analyzed the main $J_{s c}$ loss factors of a CIGS module when thinning down the absorber layer. Comparison between modules with a thick and thin absorber reveals highly reduced longwavelength absorption in CIGS and mainly enhanced parasitic absorption at the poorly reflecting Mo back contact of the thin module. To increase the $J_{s c}$ of the thin module we first introduce, in simulations, a highly a)

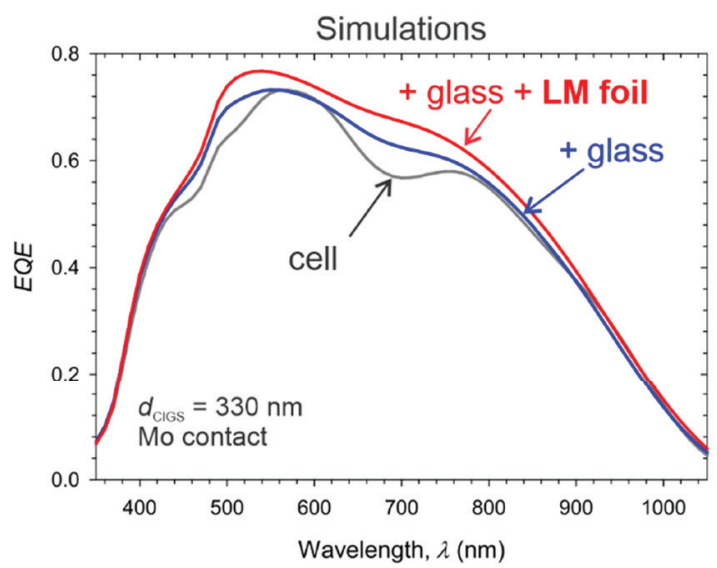

b)

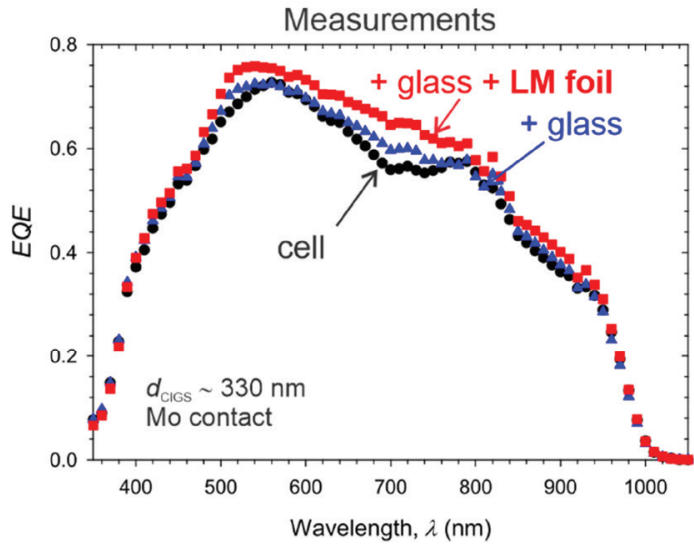

Figure 4: (a) Simulated and (b) measured EQE of an ultra-thin CIGS cell $\left(d_{\mathrm{CIGS}}=330 \mathrm{~nm}\right)$ in three configurations: bare cell (i) - black lines\&symbols, with added front glass (ii) - blue lines\&symbols and with added glass and LM foil (iii) - red lines\&symbols. Differences in long wavelength range can be contributed to different bandgap of fabricated and simulated CIGS absorber.

reflective $\mathrm{Ag} B \mathrm{~B}$, that effectively reduces absorption losses at the back contact, but still an improved $J_{\text {sc }}$ of $30.85 \mathrm{~mA} / \mathrm{cm}^{2}$ does not match the $J_{\text {sc }}$ of the device with the thick absorber. To further improve the $J_{s c^{\prime}}$ an additional texturing of the BR in combination with realistic layer growth was introduced in the simulations. Highly increased $J_{\text {sc }^{\prime}}$ surpassing the one of the thick device was observed for the $\mathrm{Ag} \mathrm{BR}$, with best result of $J_{\mathrm{sc}}=34.75$ $\mathrm{mA} / \mathrm{cm}^{2}$. Besides internal nanotextures, external microtextures were investigated by adding textured LM foil with $\mathrm{O}$ dome shaped texture on the front side of the flat device. A high $J_{s^{\prime}}$ slightly surpassing a thick standard module, was observed when using the LM foil in combination with the flat Ag BR. For external textures, an experimental verification on ultra-thin $\left(d_{\text {CIGS }}=330 \mathrm{~nm}\right)$ cells with Mo BR was carried out. Predicted improvements related to the LM foil were confirmed. 
The usage of textures (internal and external) was also simulated with standard Mo BR, but in this case only marginal improvements to the $J_{s c}$ were observed, much lower than with the use of alternative highly reflective $\mathrm{BR}$ (flat or with textures). Higher improvements in $\mathrm{J}_{\mathrm{sc}}$ for thin CIGS absorbers can be achieved using an alternative highly reflective $B R$, compared to introducing textures in combination with a standard Mo BR. Although to compensate for the $J_{s c}$ drop of thin CIGS, a combination of highly reflective back contact and introduction of textures (internal or external) is needed.

\section{Acknowledgement}

The authors acknowledge the financial support of the H2020 project ARCIGS-M (GA No. 720887 - H2020 NMBP-2016-2017).

\section{References}

1. M. Nakamura, K. Yamaguchi, Y. Kimoto, Y. Yasaki, T. Kato, and H. Sugimoto, "Cd-Free $\mathrm{Cu}(\mathrm{In}, \mathrm{Ga})(\mathrm{Se}, \mathrm{S}) 2$ Thin-Film Solar Cell With Record Efficiency of 23.35\%," IEEE J. Photovolt., vol. 9, no. 6, pp. 18631867, Nov. 2019.

https://doi.org/10.1109/JPHOTOV.2019.2937218

2. H. U. Sverdrup, K. V. Ragnarsdottir, and D. Koca, "An assessment of metal supply sustainability as an input to policy: security of supply extraction rates, stocks-in-use, recycling, and risk of scarcity," J. Clean. Prod., vol. 140, pp. 359-372, Jan. 2017. https://doi.org/10.1016/j.jclepro.2015.06.085

3. "Risk list 2015 | Commodities \& statistics | MineralsUK." [Online]. Available: http://www.bgs.ac.uk/ mineralsuk/statistics/riskList.html. [Accessed: 17Jul-2019].

4. J. Posada, M. Jubault, and N. Naghavi, "Ultra-thin $\mathrm{Cu}(\mathrm{In}, \mathrm{Ga}) \mathrm{Se} 2$ solar cells prepared by an alternative hybrid co-sputtering/evaporation process," Thin Solid Films, vol. 633, pp. 66-70, Jul. 2017. https://doi.org/10.1016/j.tsf.2016.08.015

5. N. Naghavi et al., "Ultrathin $\mathrm{Cu}(\mathrm{In}, \mathrm{Ga}) \mathrm{Se} 2$ based solar cells," Thin Solid Films, vol. 633, pp. 55-60, Jul. 2017.

https://doi.org/10.1016/j.tsf.2016.11.029

6. P. M. P. Salomé et al., "Passivation of Interfaces in Thin Film Solar Cells: Understanding the Effects of a Nanostructured Rear Point Contact Layer," Adv. Mater. Interfaces, vol. 5, no. 2, p. 1701101, 2018. https://doi.org/10.1002/admi.201701101

7. B. Vermang et al., "Introduction of Si PERC Rear Contacting Design to Boost Efficiency of $\mathrm{Cu}(\mathrm{In}, \mathrm{Ga})$
$\mathrm{Se}_{\mathrm{bf} 2_{2}}$ Solar Cells," IEEE J. Photovolt., vol. 4, no. 6, pp. 1644-1649, Nov. 2014.

https://doi.org/10.1109/JPHOTOV.2014.2350696

8. S. Suresh et al., "A study to improve light confinement and rear-surface passivation in a thin- $\mathrm{Cu}(\mathrm{In}$, Ga)Se2 solar cell," Thin Solid Films, vol. 669, pp. 399-403, Jan. 2019.

https://doi.org/10.1016/j.tsf.2018.11.027

9. S. Choi, Y. Kamikawa, J. Nishinaga, A. Yamada, H. Shibata, and S. Niki, "Lithographic fabrication of point contact with $\mathrm{Al} 2 \mathrm{O} 3$ rear-surface-passivated and ultra-thin $\mathrm{Cu}(\mathrm{In}, \mathrm{Ga}) \mathrm{Se} 2$ solar cells," Thin Solid Films, vol. 665, pp. 91-95, Nov. 2018.

https://doi.org/10.1016/j.tsf.2018.08.044

10. M. Schmid, "Review on light management by nanostructures in chalcopyrite solar cells," Semicond. Sci. Technol., vol. 32, no. 4, p. 043003, Mar. 2017. https://doi.org/10.1088/1361-6641/aa59ee

11. "The $\mathrm{COMSOL}^{\circledR}$ Software Product Suite," COMSOL Multiphysics $^{\circledR}$. [Online]. Available: https://www. comsol.com/products. [Accessed: 17-Jul-2019].

12. M. Kovacic et al., "Light management design in ultra-thin chalcopyrite photovoltaic devices by employing optical modelling," Sol. Energy Mater. Sol. Cells, vol. 200, p. 109933, Sep. 2019. https://doi.org/10.1016/j.solmat.2019.109933

13. A. Campa, J. Krc, and M. Topic, "Two Approaches for Incoherent Propagation of Light in Rigorous Numerical Simulations," Prog. Electromagn. Res., vol. 137, pp. 187-202, 2013.

https://doi.org/10.2528/PIER13010407

14. B. Lipovšek, J. Krč, and M. Topič, “Optical model for thin-film photovoltaic devices with large surface textures at the front side," Inf. MIDEM, vol. 41, no. 4, pp. 264-271, 2011.

15. J. Krc et al., "Optical and electrical modeling of $\mathrm{Cu}(\mathrm{In}, \mathrm{Ga}) \mathrm{Se} 2$ solar cells," Opt. Quantum Electron., vol. 38, no. 12, pp. 1115-1123, Sep. 2006. https://doi.org/10.1007/s11082-006-9049-1

16. Y.-C. Lin, Y.-T. Hsieh, C.-M. Lai, and H.-R. Hsu, "Impact of Mo barrier layer on the formation of MoSe2 in Cu(In,Ga)Se2 solar cells," J. Alloys Compd., vol. 661, pp. 168-175, Mar. 2016. https://doi.org/10.1016/j.jallcom.2015.11.194

17. J. Krc, J. Malmström, F. Smole, and M. Topic, "Determination of light scattering properties of $\mathrm{Cu}(\mathrm{In}, \mathrm{Ga}) \mathrm{Se} 2$ films for solar cells," Proc 20th Eur. Photovolt. Sol. Energy Conf., pp. 1831-1834, 2005.

18. L. Gouillart et al., "Development of reflective back contacts for high-efficiency ultrathin $\mathrm{Cu}(\mathrm{In}, \mathrm{Ga})$ Se2 solar cells," Thin Solid Films, vol. 672, pp. 1-6, Feb. 2019.

https://doi.org/10.1016/j.tsf.2018.12.041

19. "Principles of Lithography, Fourth Edition | (2019) | Levinson | Publications | Spie." [On- 
line]. Available: https://spie.org/publications/ book/2525392?SSO=1. [Accessed: 17-Jul-2019].

20. K. Jäger et al., "Simulations of sinusoidal nanotextures for coupling light into C-Si thin-film solar cells," Opt. Express, vol. 24, no. 6, pp. A569-A580, Mar. 2016.

https://doi.org/10.1364/OE.24.00A569

21. D. Chen et al., "Nanophotonic light management for perovskite-silicon tandem solar cells," J. Photonics Energy, vol. 8, no. 2, p. 022601, Mar. 2018. https://doi.org/10.1117/1.JPE.8.022601

22. M. Sever et al., "Combined model of non-conformal layer growth for accurate optical simulation of thin-film silicon solar cells," Sol. Energy Mater. Sol. Cells, vol. 119, pp. 59-66, Dec. 2013. https://doi.org/10.1016/j.solmat.2013.05.016

23. M. Sever, J. Krč, and M. Topič, "Prediction of defective regions in optimisation of surface textures in thin-film silicon solar cells using combined model of layer growth," Thin Solid Films, vol. 573, pp. 176184, Dec. 2014. https://doi.org/10.1016/j.tsf.2014.11.053

24. J. D. Myers et al., "A universal optical approach to enhancing efficiency of organic-based photovoltaic devices," Energy Environ. Sci., vol. 5, no. 5, pp. 6900-6904, Apr. 2012. https://doi.org/10.1039/c2ee21254d

25. B. Lipovšek et al., "Detailed optical modelling and light-management of thin-film organic solar cells with consideration of small-area effects," Opt. Express, vol. 25, no. 4, pp. A176-A190, Feb. 2017. https://doi.org/10.1364/OE.25.00A176

26. B. Lipovšek, J. Krč, and M. Topič, "Microtextured Light-Management Foils and Their Optimization for Planar Organic and Perovskite Solar Cells," IEEE J. Photovolt., vol. 8, no. 3, pp. 783-792, May 2018. https://doi.org/10.1109/JPHOTOV.2018.2810844

27. A. Peer, R. Biswas, J.-M. Park, R. Shinar, and J. Shinar, "Light management in perovskite solar cells and organic LEDs with microlens arrays," Opt. Express, vol. 25, no. 9, pp. 10704-10709, May 2017. https://doi.org/10.1364/OE.25.010704
28. Louis Gouillart, Wei-Chao Chen, Andrea Cattoni, Julie Goffard, Lars Riekehr, Jan Keller, Marie Jubault, Negar Naghavi, Marika Edoff, Stéphane Collin, "Reflective Back Contacts for Ultrathin Cu (In, Ga) Se2-Based Solar Cells", IEEE Journal of Photovoltaics, 2019, PP(99); 1-5, October 2019. https://doi.org/10.1109/JPHOTOV.2019.2945196

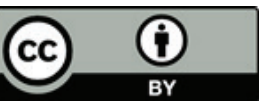

Copyright (c) 2019 by the Authors. This is an open access article distributed under the Creative Commons Attribution (CC BY) License (https://creativecommons.org/licenses/by/4.0/), which permits unrestricted use, distribution, and reproduction in any medium, provided the original work is properly cited.

Arrived: 31.07. 2019

Accepted: 13. 12. 2019 